\title{
CONSTRUCTION AND ENVIRONMENTAL CONTROL OF A SMALL- SCALE FISH TANK FOR BREEDING AND PRODUCING FRESHWATER FISH
}

\author{
Safaa E. Gharib ${ }^{1 *}$, M.M. Morad ${ }^{2}$, Hend A.M. El-Maghawry ${ }^{2}$ and A.I. Abd El-Rahman ${ }^{1}$ \\ 1. Agric. Eng. Res. Inst., Agric. Res. Cent., Giza, Egypt \\ 2. Agric. Eng. Dept., Fac. Agric., Zagazig Univ., Egypt
}

\begin{abstract}
Two small-scale designed fish tanks (round and square) were constructed for breeding and producing freshwater fish. To control environment, experiments were carried out to study the effect of some different parameters on the performance of the two designed tanks during aquaculture of Nile tilapia (Oreochromis niloticus). Performance was experimentally investigated as a function of change in tank shape, fish stocking density, with and without biological filter, and aeration regime in terms of ammonia concentration, dissolved oxygen, biomass, dead fish, body weight gain, specific growth ratio, relative growth ratio and required power. The experimental results reveal that biomass vlaues of $13.53 \mathrm{~kg} / \mathrm{m}^{3}$ and $12.68 \mathrm{~kg} / \mathrm{m}^{3}$ were maximum while dead fish values of $3 \mathrm{fish} / \mathrm{m}^{3}$ and $9 \mathrm{fish} / \mathrm{m}^{3}$ were optimum under the following conditions: use of the round and square tanks, respectively adjust air compressor with inter-holes distance of $150 \mathrm{~mm}$ as an aeration regime and adjust stocking density at $200 \mathrm{fish} / \mathrm{m}^{3}$.
\end{abstract}

Key words: Aquaculture, Nile tilapia, tank shape, fish stocking density, aeration regime, dissolved oxygen, ammonia concentration.

\section{INTRODUCTION}

Fish is one of the most important sources of protein food. This is characterized by many health benefits that make it first major food for people eat. Fish is also characterized by the short life cycle to reach commercial size and weight. Because fish production in Egypt resulting from lakes and sources of fresh water, which is estimated at about 387 thousand tons does not meet domestic consumption, which leads to import about 220 thousand tons/year. So, tended to encourage state aquaculture for producing about 668 thousand tons/year (Central Agency for Public Mobilization and Statistics, 2011). Aquaculture development project are initiated in many parts of the world especially in the developing countries.

Fish farming has virtually become the main hope of the growing of the Egyptian population for achieving an optimistic animal-protein target to compensate the deficiency in meat production, in addition to fish as component of traditional Egyptian diet. World aquaculture Production in 2012 was estimated at around 66.5 million tones. Aquaculture contributed $40.1 \%$ to the world total fish production, in 2011, the top20 producers produced $95 \%$ of world farmed food fish, Egypt is among the top producers it ranked $8^{\text {th }}$ and produced 919585 tonnes (FAO 2012).

Teichert and Green (1993) evaluated the effect of aeration and dissolved oxygen (DO) regulation on growth and yield of fish. They applied three treatments on aeration. The first was without any aeration. In the second, aeration started when DO reach $10 \%$ saturation and the third aeration started when DO reached 30\% saturation. They reported that tilapia yield and growth were higher more under aerating treatments. Boyd (1998) used different procedures to increase (DO) concentration in pond include: Exchanging part of oxygen

* Corresponding author: Tel. : +201146397574

E-mail address: safaaom.omar@yahoo.com 
depleted pond water with oxygenate water from well pond; application of fertilizer to simulate oxygen production by photosynthesis; inject pure oxygen into pond water; aeration by mechanical devices and addition of compounds which release oxygen through chemical reaction. EI-Sayed (2002) found that the increasing of stocking density may cause deterioration in water quality leading to stressful conditions. Abdelhamid (2003) reported that, Nile tilapia tolerate low temperature till $8^{\circ} \mathrm{C}$ for 3 - 4 hours, but $12^{\circ} \mathrm{C}$ is lethal; yet, they live longer at $15^{\circ} \mathrm{C}$ and spawning occurs at 22 $24^{\circ} \mathrm{C}$. The highest lethal temperature is $42^{\circ} \mathrm{C}$. Liti et al. (2005) found that the growth rate of Nile tilapia was significantly $(\mathrm{P}<0.05)$ higher when stocked at low density than the high density. Aksungur et al. (2007) found that the fish survival rate significantly $(\mathrm{P}<0.05)$ declined in high stocking density (90 and 120 fish $/ \mathrm{m}^{2}$ ) probably due to high stocking rate and increasing temperature than the low stocking density (30 and 61)fish $\mathrm{m}^{2}$ ). Li et al. (2008) mentioned that dissolved oxygen (DO) concentration can be often maintained above 7.0 $\mathrm{mg} / \mathrm{l}$ when $0.15 \mathrm{MPa}$ pressure of liquid oxygen was kept in an intensive Litopenaeus vannamei farming. The distribution of DO in farming ponds was uniformity, and DO stratification did not occur. The running-cost of liquid oxygen aerating was lower than that of power aerating. Lopa and Tiwari (2008) performed parametric study to represent the effects of pond depth and secchi disc depth (SDD), extinction coefficient, water temperature and fish yield changes on DO regimes in fish pond. Dissolved oxygen concentrations in the pond varied with both pond depth and SDD. The low DO values in the shallow pond $(0.5 \mathrm{~m})$ with a high SDD $(0.5 \mathrm{~m})$ when compared to other ponds with SDD equal to their pond depths, was the result of low overall oxygen production relative to the demand by sediment and fish, which were same for all depths of pond. Ayyat et al. (2011) found that the fina1 live body weight and daily body gain of Nile tilapia fish decreased with increasing stocking density. Average daily weight gain decreased with $11.86 \%$ in fish reared at high density (200 fish $/ \mathrm{m}^{2}$ ) compared to those reared at $100 \mathrm{fish} / \mathrm{m}^{2}$, at the whole of the experimental period. They also found that the concentrations of dissolved oxygen and $\mathrm{pH}$ in water decreased with increasing fish density, while the concentrations of ammonia, nitrite and nitrate were increased.
All these efforts did not bridge the gap between the quantities supplied and the growing demand for fish. To raise the efficiency of fish farming to reach the highest productivity, it is of great importance to provide the elements of high fish growth, therefore increase production. The most important of these elements are water temperature, dissolved oxygen and ammonia concentration, beside that a good fodder. In addition, fish need oxygen for aerobic generation of energy for body maintenance locomotion feeding and biosynthesis.

So, the objectives of the present investigation are to:

- Construct and control environment of a smallscale fish tank for breeding and producing freshwater fish.

- Evaluate some different parameters (tank shape, fish stocking density, with and without biological filter and aeration regime) affecting Nile tilapia production.

\section{MATERIALS AND METHODS}

The main experiments were carried out during the period from June to September 2015 at a private farm, Sharkia Governorate, Egypt.

\section{Materials}

\section{Nile tilapia fish}

The fingerling of Nile tilapia (Oreochromis niloticus) were obtained from Center Laboratory for Aquaculture Research at Abbassa, Sharkia Governorate, Egypt. The experimental fish weight is of 10 gram.

\section{Fish diet}

All fish groups were fed on basal pelleted diet consists of fish meal 30\%, soybean meal $20 \%$, corn $20 \%$, wheat bran $15 \%$, alfalfa hay $10 \%$, sunflower oil $2.5 \%$, minerals mixture $0.5 \%$, vitamin mixture $1 \%$ and Carboxymethyl celluose $1 \%$. The chemical composition of the diet was crude protein $40.12 \%$, ether extract $6.40 \%$, crude fiber $5.32 \%$ and gross energy $4280.0 \mathrm{Kcal} / \mathrm{Kg}$. The feeding rate was $3 \%$ of live body weight and the experimental diets were offered three times daily (8: $00 \mathrm{am}, 12: 00$ am and $17: 00 \mathrm{pm}$ ). 


\section{Water quality}

Water quality parameters (pH, ammonia concentration, nitrite and nitrate) were monitored every ten days before replacing all the water by freshwater and replacing $10 \%$ of the water every day in the aquarium during the experimental period. The water chemical analyses were carried out according to APHA (1989).

The standard specifications of the used water was tabulated in Table 1.

Water temperature was adjusted at $28^{\circ} \mathrm{C}$, which was measured by Thermometer (YSI model 58, Yellow Spring Instrument Co., Yellow Spring, Ohio, USA). Temperature of $28^{\circ} \mathrm{C}$ is the recommended and the suitable value for Nile tilapia.

The $\mathrm{pH}$ degree of water samples was measured by using a pH meter (Digital Mini-PH Meter, model 55, Fisher scientific, Denver, USA).

\section{The constructed tanks}

Two shapes of tanks were constructed: round and square tanks.

\section{Round tank}

The round tank was constructed from highdensity polyethylene. With $1 \mathrm{~m}$ diameter and $1 \mathrm{~m}$ depth. Wastes can be removed by create a central drain in the tank bottom (Fig. 1).

\section{Square tank}

The square tank was also constructed from high-density polyethylene. With dimensions of $100 \times 100 \times 100 \mathrm{~cm}$ and sloping bottom for removing wastes to ward drain at one end; wastes tend to be collected in the corner (Fig. 2).

Both round and squired tanks were provided with the following parts:

\section{Air compressor}

The air compressor is used for aeration. It's specifications: pressure $0.8 \mathrm{MPa}$ ( $8 \mathrm{bar}$ ), motor $3 \mathrm{hp}$ (2.2 kW), capacity $170 \mathrm{l} / \mathrm{min}$, and tank volume is $100 \mathrm{l}$. The pipe diameter of the air compressor is $4 \mathrm{~mm}$ while its holes diameter is $25 \mathrm{~mm}$.

\section{Manometer}

The manometer $12 \times 10^{5} \mathrm{~Pa}$ is used to measure air pressure into the air hose.

\section{Timer}

The timer was adjusted to connect the compressor electric circle (ON position) through 15 minutes, and cut out (OFF position) for 15 minutes.

\section{Heater}

The heater supplied with thermostat digital was used and each tank was provided with four heaters with power of 300 Watt for each.

\section{Biological filter}

Closed, or recirculating, aquaculture systems use biological filters to remove accumulated metabolic fish wastes. Left untreated, the buildup of metabolic wastes such as ammonia lead to lower fish production and eventually death of the cultured fish. Ammonia can be broken down by bacteria into a relatively non-toxic form of inorganic nitrogen, nitrate. The conversion of ammonia to nitrate is a two step process where nitrifying bacteria convert ammonia to nitrite and then nitrite to nitrate. A trickling filter provides a large surface area for attachment of nitrifying bacteria to biologically "filter" ammonia from water.

The biological filter is formed from nets, the first one with holes diameter of $1 \mathrm{~mm}$., the second has holes of less than the first one diameter that full of sponge, the third contents coal and bio-ceramic balls with diameter of 25 $\mathrm{mm}$, the bacteria and the bio-chemical cotton were lies in the last part of the biological filter (Fig. 3).

The bacteria, nitrosomonas and nitrobacter were kindly supplied from Agriculture Microbiology department, faculty of Agriculture Zagazig Univ., Egypt.

\section{Methods}

Experiments were conducted to control environment and evaluate the performance of two different shapes of small-scale fish tanks for breeding and producing freshwater fish.

\section{Experimental conditions}

The performance of the two shapes of smallscale fish tanks was experimentally measured under the following parameters:

- Two different shapes of tanks (round and square).

- Three different fish stocking densities of 100 , 150 and $200 \mathrm{fish} / \mathrm{m}^{3}$.

- With and without biological filter. 
Table 1. Standard specifications of the used water

\begin{tabular}{cccccc}
\hline Temperature & Ammonia concentration & Nitrite & Nitrate & pH & Dissolved Oxygen \\
\hline $25-28^{\circ} \mathrm{C}$ & $0.125 \mathrm{mg} / \mathrm{l}$ & $0.2 \mathrm{mg} / \mathrm{l}$ & $3-5 \mathrm{mg} / \mathrm{l}$ & $6.5-9$ & $5-10 \mathrm{mg} / \mathrm{l}$ \\
\hline
\end{tabular}

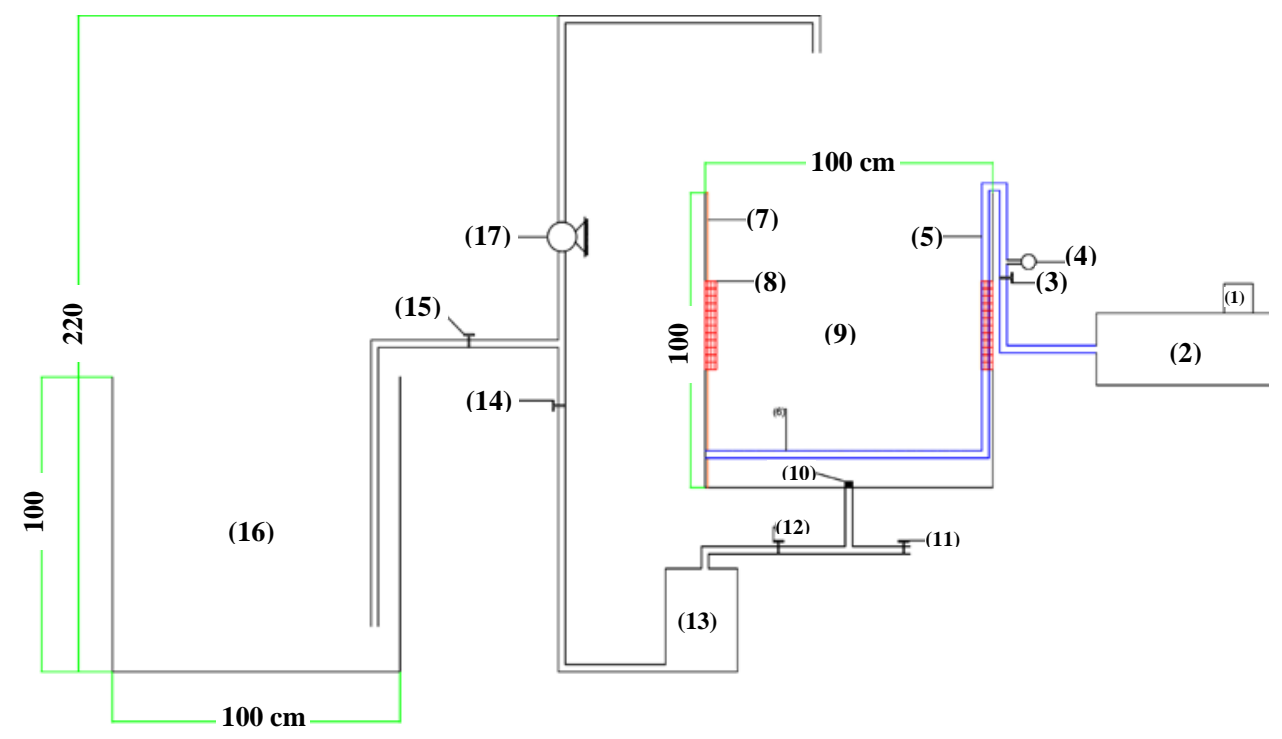

Fig.1: Elevation view of round tank
1- Timer
2- Compressor
3- Control valve 4- manometer
5- Air pipe
6- Drilled pipe
7- Wood holder
9- Tank
10- drain hole
13- Biological filter
16- Fresh water
17- Water pump
11, 12, 14,15- Control valve

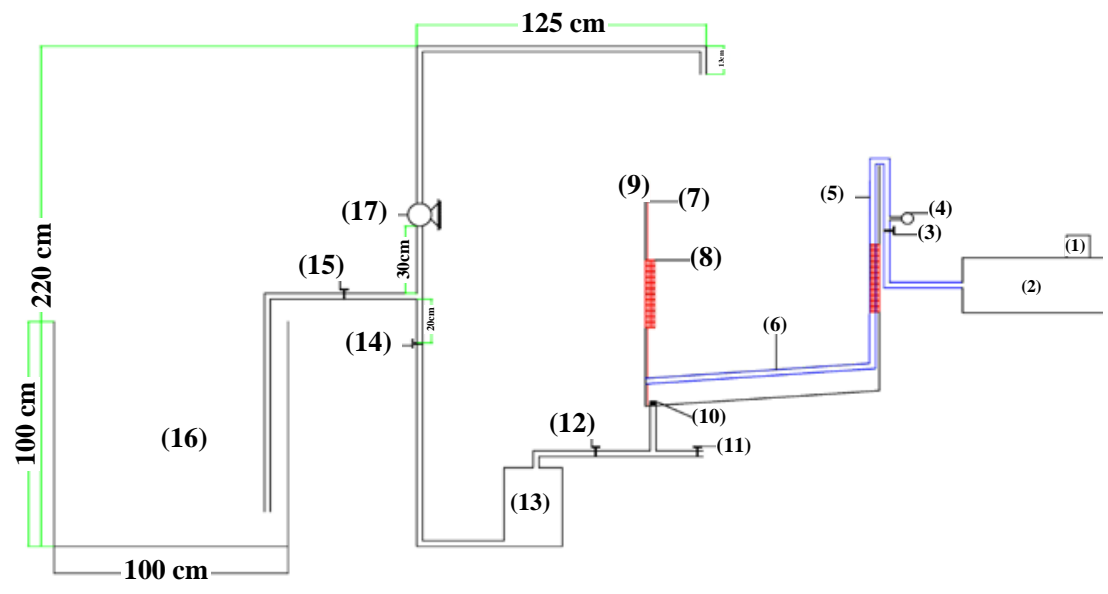

Fig. 2. Elevation view of square tank
1- Timer
2- Compressor
3-Control valve 4- manometer
5- Air pipe
6- Drilled pipe
7- wood holder
8- Heater
9- Tank
10- drain hole
3- Biological filter
16- Fresh water
17- water pump $11,12,14,15$. Control valve 


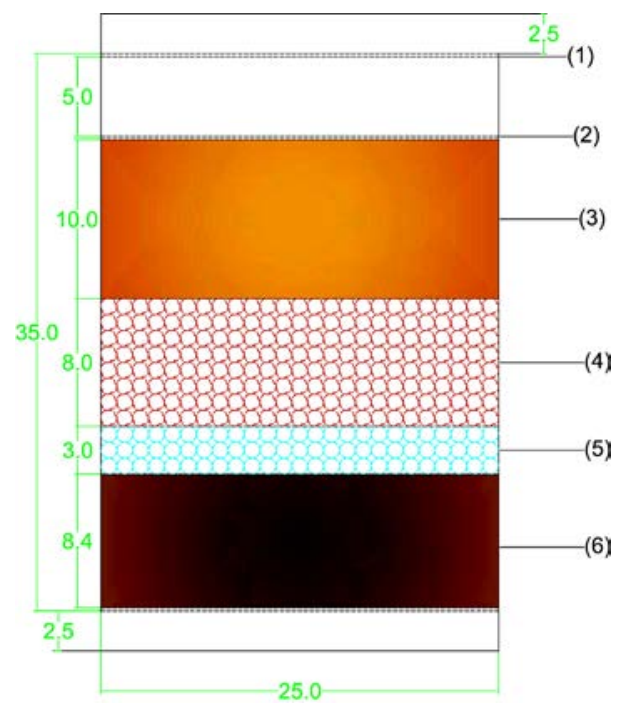

Fig. 3. Section elevation of biological filter
1, 2- Material net
3- Sponge
4- coal
5- Bio- ceramic balls
6- Bio - chemical cotton.

- Three aeration regimes:

- Aeration by air compressor with inter-holes distance of $150 \mathrm{~mm}$ (A1) corresponding to air flow rate of $0.018 \mathrm{~m}^{3} / \mathrm{sec}$.

- Aeration by air compressor with inter-holes distance of $200 \mathrm{~mm}$ (A2) corresponding to air flow rate of $0.015 \mathrm{~m}^{3} / \mathrm{sec}$.

- Aeration by air compressor with inter-holes distance of $250 \mathrm{~mm}$ (A3) corresponding to air flow rate of $0.012 \mathrm{~m}^{3} / \mathrm{sec}$.

\section{Measurements and determinations}

Performance evaluation of the two shapes of small-scale fish tanks was based on the following indicators:

\section{Air flow rate}

The air flow rate passing through one hole

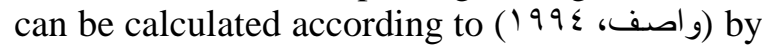
the following equation:

$$
\mathrm{q}=\left[\pi \times \mathrm{R}^{4} \times(\mathrm{p}-\rho \mathrm{gh})\right] /[8 \times \eta \times 1]
$$

Where:

q- Air flow for one hole, $\mathrm{m}^{3} / \mathrm{sec}$.

$\pi$ - Pi constant, 3.143

R- Radius of hole, $2 \mathrm{~mm}$

p- Air pressure, $\mathrm{N} / \mathrm{m}^{2}$ $\rho$ - Water density, g/ $\mathrm{cm}^{3}$

g- Gravity wheel value, $\left(9.81 \mathrm{~m} / \mathrm{sec}^{2}\right)$

h- Water head, (m)

$\eta$ - Air viscosity factor, $19 \times 10-6$ N.sec. $/ \mathrm{m}^{2}$

l- Path length, m.

The total air flow rate of pumped air $\left(\mathrm{Q}, \mathrm{m}^{3} /\right.$ sec.) can be estimated by calculating the sum of air flow rate $\left(\mathrm{Q}, \mathrm{m}^{3} / \mathrm{sec}\right.$.) of each hole.

\section{Ammonia concentration}

Total ammonia concentration was measured directly by $\mathrm{HACH}$ comparison apparatus using HACK kits (Hach Co., Loveland, CO, USA).

\section{Dissolved oxygen}

Dissolved oxygen was measured directly by using oxygen- meter apparatus (YSI model 58, Yellow Spring Instrument Co., Yellow Spring, Ohio, USA).

\section{Biomass of tilapia}

Biomass of tilapia was weighted for each treatment during the experimental period.

\section{Dead fish of tilapia}

Number of dead fish was counted for each treatment during the experimental period. 


\section{Body weight gain}

Body weight gain was calculated using the following equation:

Body weight gain (g/fish)=final weight-initial weight

\section{Specific growth rate (SGR)}

SGR was calculated according to Laird and Needham (1988) by the following equation:

SGR $=\frac{\text { Log final mean body weight }- \text { Log initial mean body weight }}{\text { Time intervals }(\text { day })} \times 100$

\section{Relative growth rate}

Relative growth rate was measured as follows:

$$
\text { RGR }=\frac{\text { Final weight }- \text { initial weight }}{\text { Initial weight }} \times 100
$$

\section{Required power}

The required power was calculated by using both ammeter and voltmeter which were used for measuring current strength and voltage. The following formula (Ibrahim, 1982) was used for estimating power for operating air compressor:

$$
\mathrm{P}=\mathrm{I} \times \mathrm{V} \times \cos \theta
$$

Where

$\mathrm{P}$ - required power, $\mathrm{kW}$.

I - current strength in amperes.

$\mathrm{V}$ - voltage in volts being equal to $220 \mathrm{~V}$.

$\operatorname{Cos} \theta$ - power factor Being equal to 0.96

$\Theta$ - phase angle between $\mathrm{V}$ and I

\section{RESULTS AND DISCUSSION}

The discussion will cover the obtained results under the following heads:

\section{Effect of Aeration Regime on Ammonia Concentration for Round and Square Tanks}

Fig. 4 shows the relationship between the aeration regime and ammonia concentration with and without biological filter in round tank under different Nile tilapia stocking densities.

Concerning the round tank without biological filter, data showed that ammonia concentration values under Nile tilapia stocking density of 100 fish/ $\mathrm{m}^{3}$ were $0.06,0.15$, and $0.19 \mathrm{mg} / \mathrm{l}$ under aeration regimes $\mathrm{A} 1, \mathrm{~A} 2$, and $\mathrm{A} 3$, respectively. while they were $0.35,0.42$, and $0.63 \mathrm{mg} / \mathrm{l}$ under $150 \mathrm{fish} / \mathrm{m}^{3}$. In addition, they were $0.8,1.06$, and $1.3 \mathrm{mg} / \mathrm{l}$ under $200 \mathrm{fish} / \mathrm{m}^{3}$ under the same previous aeration regimes. As to the round tank with biological filter, data showed that ammonia concentration values at Nile tilapia stocking density of $100 \mathrm{fish} / \mathrm{m}^{3}$ were $0.00,0.00$, and 0.02 $\mathrm{mg} / \mathrm{l}$ under aeration regimes $\mathrm{A} 1, \mathrm{~A} 2$, and $\mathrm{A} 3$, respectively. while they were $0.00,0.01$ and $0.03 \mathrm{mg} / \mathrm{l}$ under $150 \mathrm{fish} / \mathrm{m}^{3}$. In addition, the ammonia concentration values at stocking density of $200 \mathrm{fish} / \mathrm{m}^{3}$ were $0.02,0.06$, and 0.15 $\mathrm{mg} / \mathrm{l}$ under the same previous aeration regimes.

On the other side in the case of using the square tank without biological filter, the ammonia concentration values at Nile tilapia stocking density of $100 \mathrm{fish} / \mathrm{m}^{3}$ were $0.20,0.34$ and $0.51 \mathrm{mg} / \mathrm{l}$ under aeration regimes A1, A2 and A3, respectively. Meanwhile ammonia concentration values at stocking density of 150 fish $/ \mathrm{m}^{3}$ were $0.46,0.57$ and $0.83 \mathrm{mg} / \mathrm{l}$. In addition, the ammonia concentration values at stocking density of $200 \mathrm{fish} / \mathrm{m}^{3}$ were $0.92,1.34$ and $1.47 \mathrm{mg} / \mathrm{l}$ under the same previous aeration regimes. As to the square tank with biological filter, data showed that ammonia concentration values at Nile tilapia stocking density of 100 fish $/ \mathrm{m}^{3}$ were $0.00,0.01$ and $0.04 \mathrm{mg} / \mathrm{l}$ under aeration regimes A1, A2 and A3, respectively. Meanwhile ammonia concentration at stocking density of $150 \mathrm{fish} / \mathrm{m}^{3}$ were $0.01,0.04$, and 0.08 $\mathrm{mg} / \mathrm{l}$. Also, ammonia concentration at stocking density of $200 \mathrm{fish} / \mathrm{m}^{3}$ were $0.02,0.08$, and 0.24 $\mathrm{mg} / \mathrm{l}$ under the same previous aeration regimes.

The results showed that ammonia concentration values increased with increasing fish density. Their values exceeded the recommended value $(0.125 \mathrm{mg} / \mathrm{l})$ at high fish densities.

The above mentioned results showed that ammonia concentration values for both round and square tanks without using biological filter exceeded the recommended value $(0.125 \mathrm{mg} / \mathrm{l})$, which considered very dangerous for fish.

The results showed that the lowest ammonia concentration values were achieved under using 

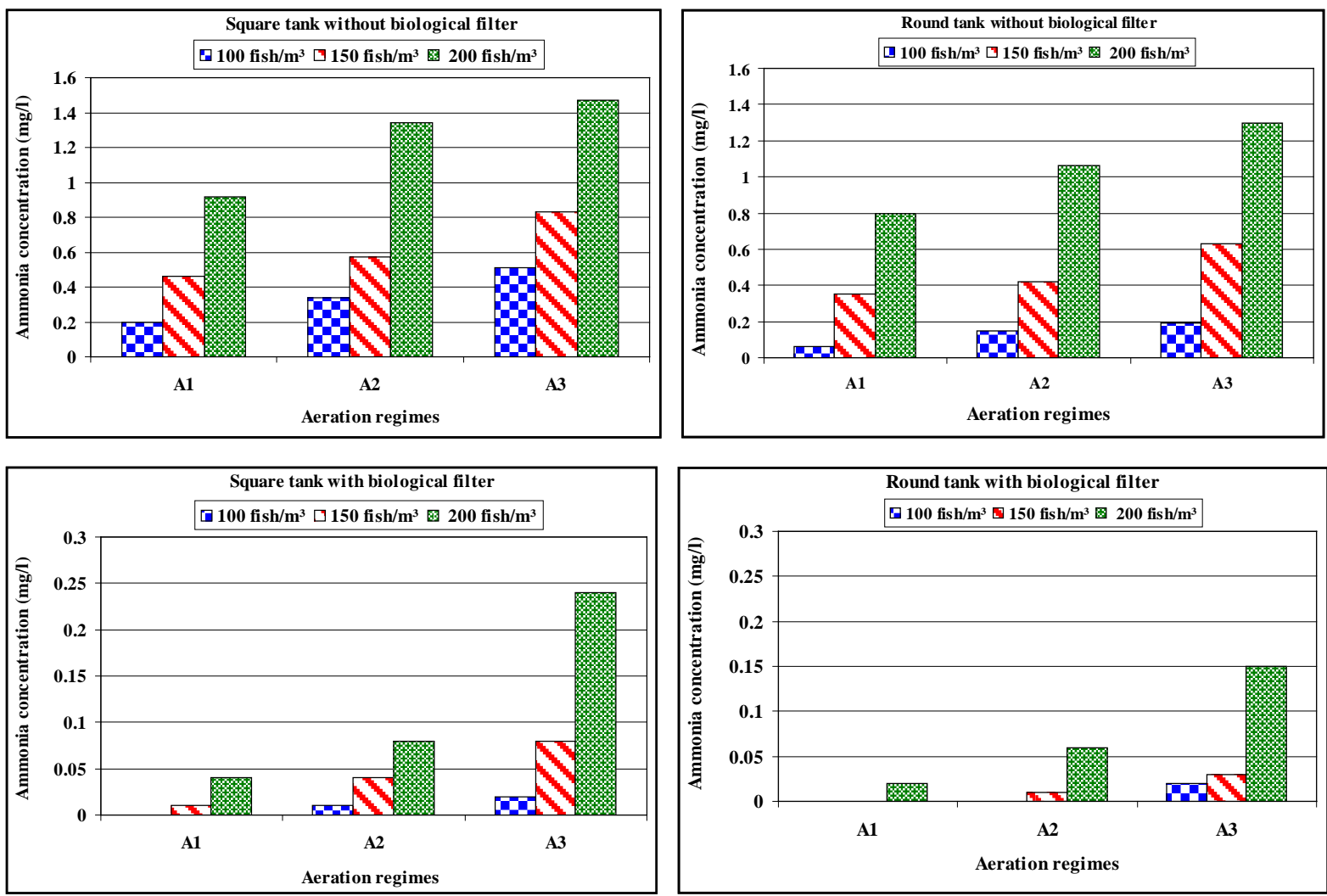

Fig. 4. Effect of aeration regime on ammonia concentration with and without biological filter in square and round tanks under different Nile tilapia stocking densities

biological filter and aeration regime A1 (aeration by air compressor with inter-holes distance of $150 \mathrm{~mm}$ ) with the use of either round or square tanks.

\section{Effect of Aeration Regime on Dissolved Oxygen for Round and Square Tanks}

Fig. 5 shows the relationship between the aeration regime and dissolved oxygen for both round and square tanks under different Nile tilapia stocking densities during the first month.

Concerning the round tank, data showed that dissolved oxygen values at Nile tilapia stocking density of $100 \mathrm{fish} / \mathrm{m}^{3}$ were $7.7,6.9$ and $6.5 \mathrm{mg} / \mathrm{l}$ under aeration regimes $\mathrm{A} 1, \mathrm{~A} 2$ and $\mathrm{A} 3$, respectively. Meanwhile dissolved oxygen values at stocking density of $150 \mathrm{fish} / \mathrm{m}^{3}$ were 6.8, 5.9 and $5.5 \mathrm{mg} / \mathrm{l}$. In addition, the dissolved oxygen values at stocking density of $200 \mathrm{fish} / \mathrm{m}^{3}$ were $5.8,5.5$ and $5.1 \mathrm{mg} / \mathrm{l}$ under the same previous aeration regimes. With regard to the square tank, data showed that dissolved oxygen values at Nile tilapia stocking density of 100 fish $/ \mathrm{m}^{3}$ were $7.5,6.8$, and $6.4 \mathrm{mg} / \mathrm{l}$ under aeration regimes $\mathrm{A} 1, \mathrm{~A} 2$, and $\mathrm{A} 3$, respectively. Meanwhile dissolved oxygen at stocking density of $150 \mathrm{fish} / \mathrm{m}^{3}$ were $6.7,5.7$ and $5.3 \mathrm{mg} / \mathrm{l}$. Also the dissolved oxygen at stocking density 200 fish/ $\mathrm{m}^{3}$ were $5.6,5.3$ and $5.0 \mathrm{mg} / \mathrm{l}$ under the same previous aeration regimes.

Fig. 6 shows the relationship between the aeration regime and dissolved oxygen for both round and square tanks using different Nile tilapia stocking density during the second month.

Concerning the round tank, data showed that dissolved oxygen values at Nile tilapia stocking density of $100 \mathrm{fish} / \mathrm{m}^{3}$ were $7.12,6.55$, and 6.15 $\mathrm{mg} / \mathrm{l}$ under aeration regimes A1, A2 and A3, respectively. Meanwhile dissolved oxygen values at stocking density of $150 \mathrm{fish} / \mathrm{m}^{3}$ were 6.3, 5.6 and $5.0 \mathrm{mg} / \mathrm{l}$. Also the dissolved oxygen values at stocking density of $200 \mathrm{fish} / \mathrm{m}^{3}$ were 5.2, 4.6 and $4.35 \mathrm{mg} / \mathrm{l}$ under the same previous aeration regimes. Referring to the square tank, 

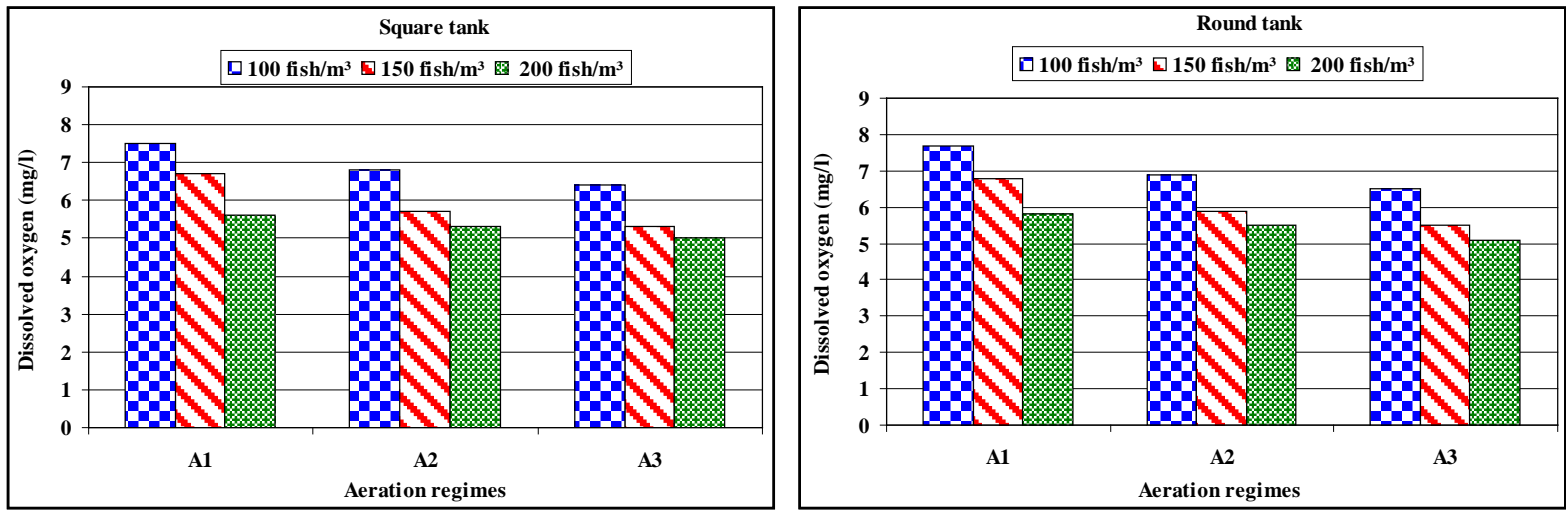

Fig. 5. Effect of aeration regimes on dissolved oxygen for round and square tanks using different stocking densities in first month
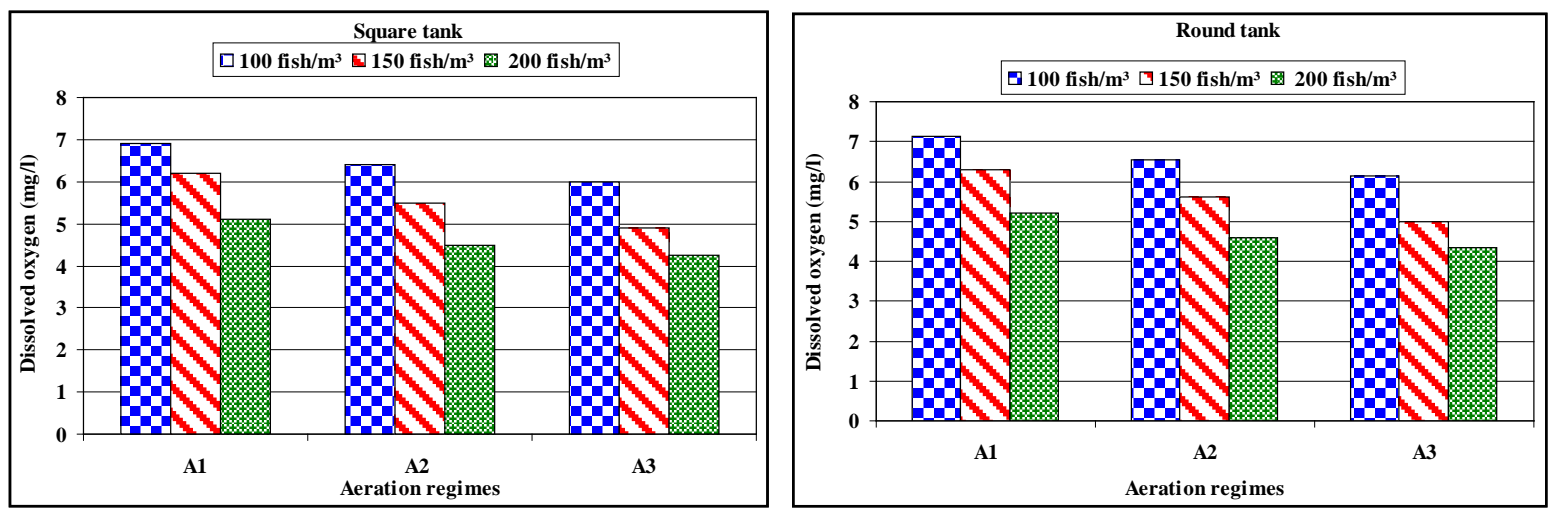

Fig. 6. Effect of aeration regimes on dissolved oxygen for round and square tanks using different stocking densities in second month

data showed that dissolved oxygen values in Nile tilapia stocking density of $100 \mathrm{fish} / \mathrm{m}^{3}$ were 6.9 , 6.4, and $6 \mathrm{mg} / \mathrm{l}$ under aeration regimes A1, A2, and $\mathrm{A} 3$, respectively. Meanwhile dissolved oxygen values at stocking density of $150 \mathrm{fish} /$ $\mathrm{m}^{3}$ were $6.2,5.5$, and $4.9 \mathrm{mg} / \mathrm{l}$. In addition, the dissolved oxygen values at stocking density of $200 \mathrm{fish} / \mathrm{m}^{3}$ were 5.1, 4.5 and $4.25 \mathrm{mg} / \mathrm{l}$ under the same previous aeration regimes.

Fig. 7 shows the relationship between the aeration regime and dissolved oxygen for both round and square tanks using different Nile tilapia stocking density during the third month.

Concerning the round tank, data showed that dissolved oxygen values at Nile tilapia stocking density of $100 \mathrm{fish} / \mathrm{m}^{3}$ were $6.15,4.96$, and 4.8 mg/l under aeration regimes A1, A2 and A3, respectively. Meanwhile dissolved oxygen values at stocking density of $150 \mathrm{fish} / \mathrm{m}^{3}$ were 5.14, 4 and $3.87 \mathrm{mg} / \mathrm{l}$. Also, the dissolved oxygen values at stocking density of $200 \mathrm{fish} / \mathrm{m}^{3}$ were 4.13, 3.5 and $3.31 \mathrm{mg} / \mathrm{l}$ under the same previous aeration regimes. As to the square tank, data showed that dissolved oxygen values in Nile tilapia stocking density of $100 \mathrm{fish} / \mathrm{m}^{3}$ were 6 , 4.86, and $4.76 \mathrm{mg} / \mathrm{l}$ under aeration regimes $\mathrm{A} 1$, A2 and A3, respectively. Meanwhile dissolved oxygen values at stocking density of $150 \mathrm{fish} / \mathrm{m}^{3}$ were $4.96,3.89$ and $3.65 \mathrm{mg} / \mathrm{l}$. In addition, the dissolved oxygen values at stocking density of $200 \mathrm{fish} / \mathrm{m}^{3}$ were $4.00,3.40$ and $3.12 \mathrm{mg} / \mathrm{l}$ under the same previous aeration regimes. 

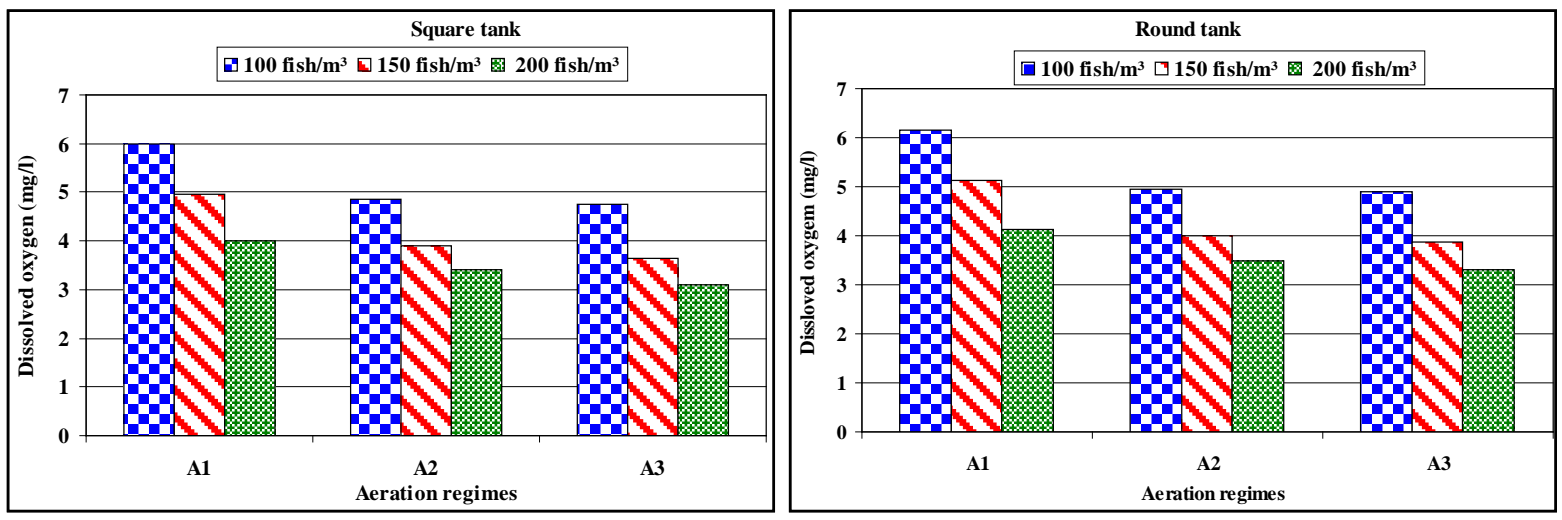

Fig. 7. Effect of aeration regimes on dissolved oxygen for round and square tanks using different stocking densities in third month

The results showed that the concentrations of dissolved oxygen in water decreased with increasing fish density due to the increase of oxygen requirements under high fish densities.

The results showed that the highest dissolved oxygen values were achieved under aeration regime A1 (Aeration by air compressor with inter-holes distance of $150 \mathrm{~mm}$ ) with the use of round tank during first, second and the third months. This attributed to that this aeration regime caused the highest dissolved oxygen in fish tanks.

The results also showed that dissolved oxygen values of the first month were higher than of the second month and values of the second month were higher than the third months. This attributed to that oxygen requirements increased with increasing fish weight.

\section{Effect of Aeration Regime on Biomass of Tilapia for Round and Square Tanks Under Different Stocking Densities}

Fig. 8 shows the relationship between aeration regime and biomass for both round and square tanks under different stocking densities.

Concerning the round tank, data showed that biomass values in Nile tilapia stocking density of $100 \mathrm{fish} / \mathrm{m}^{3}$ were $7.88,7.72$, and $7.32 \mathrm{~kg} / \mathrm{m}^{3}$ under aeration regimes A1, A2 and A3, respectively. While biomass values at stocking density of $150 \mathrm{fish} / \mathrm{m}^{3}$ were $11.33,10.89$ and $10.38 \mathrm{~kg} / \mathrm{m}^{3}$. Also the biomass values at stocking density of $200 \mathrm{fish} / \mathrm{m}^{3}$ were 13.53, 12.94 , and $12.43 \mathrm{~kg} / \mathrm{m}^{3}$ under the same previous conditions. Considering the square tank, data showed that biomass values in Nile tilapia stocking density of $100 \mathrm{fish} / \mathrm{m}^{3}$ were $7.78,7.13$ and $6.79 \mathrm{~kg} / \mathrm{m}^{3}$ under aeration regimes $\mathrm{A} 1, \mathrm{~A} 2$, and $\mathrm{A} 3$, respectively. While biomass values at stocking density of $150 \mathrm{fish} / \mathrm{m}^{3}$ were 10.74 , 10.32 , and $9.79 \mathrm{~kg} / \mathrm{m}^{3}$. Also, the biomass values at stocking density of $200 \mathrm{fish} / \mathrm{m}^{3}$ were 12.68 , 12.41 , and $11.79 \mathrm{~kg} / \mathrm{m}^{3}$ under the same previous conditions.

The biomass of Nile ti1apia fish increased with increasing stocking density. The highest values of biomass were achieved under high density $\left(200 \mathrm{fish} / \mathrm{m}^{3}\right)$ compared to those reared at 100 , and $150 \mathrm{fish} / \mathrm{m}^{3}$, at the whole of the experimental period. This is in agreement with Cruz and Delacruz (1991) who found that the total biomass yield increased with the increase of fish stocking density.

The results showed that the highest biomass value was $13.53 \mathrm{~kg} / \mathrm{m}^{3}$ which achieved under aeration regime A1 (Aeration by air compressor with inter-holes distance of $15 \mathrm{omm}$ ) with the use of round tank and density of $200 \mathrm{fish} / \mathrm{m}^{3}$.

\section{Effect of Aeration Regime on Dead Fish of Tilapia for Round and Square Tanks Under Different Stocking Densities}

Fig. 9 shows the relationship between aeration regime and dead fish for both round and square tanks using different stocking densities. 

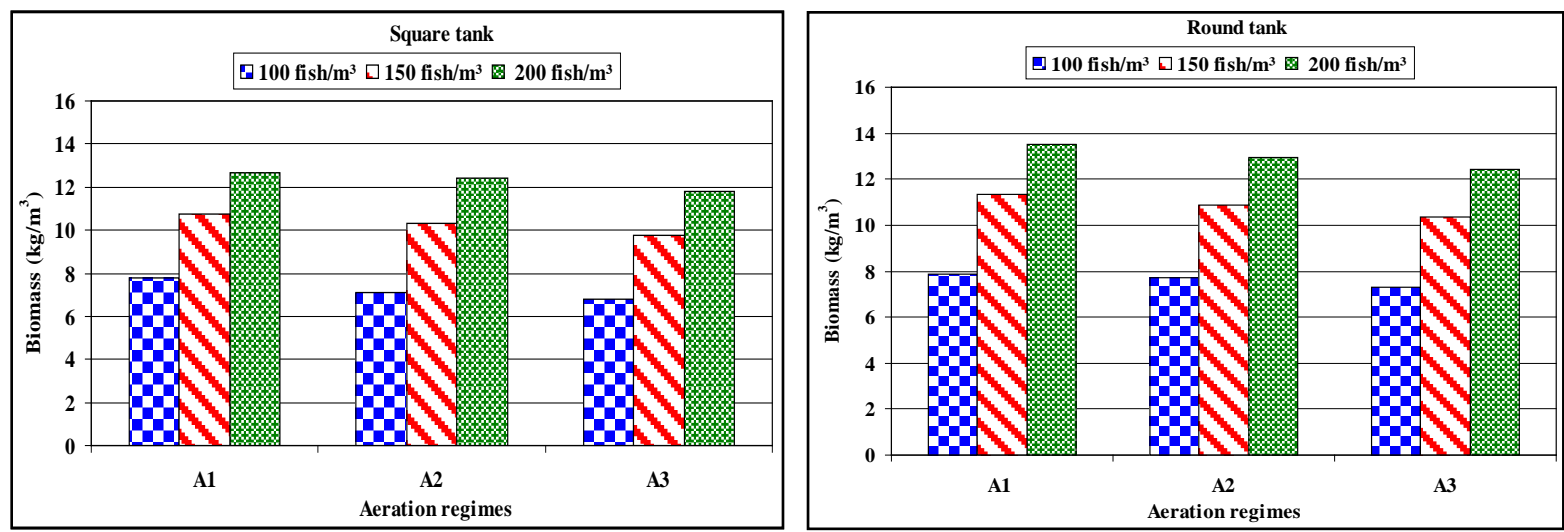

Fig. 8. Effect of aeration regimes on biomass of Nile tilapia in round and square tanks using different stocking densities
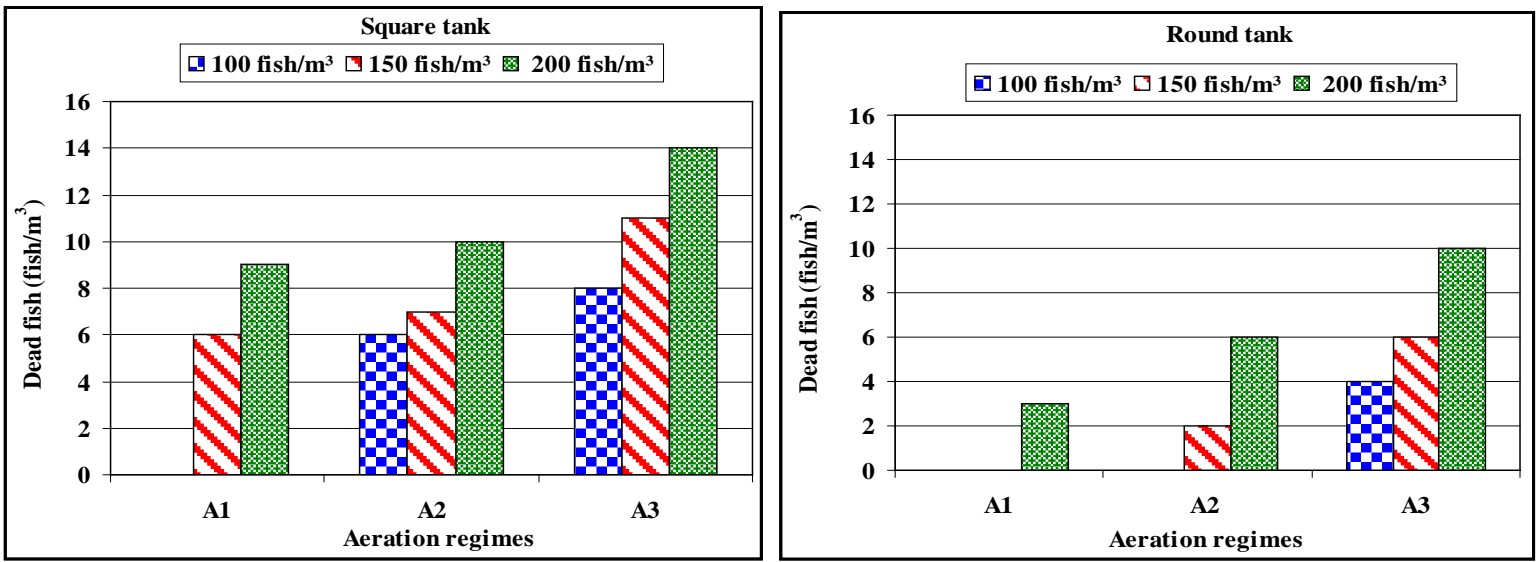

Fig. 9. Effect of aeration regime on dead fish of Nile tilapia in round and square tanks using different stocking densities

Concerning the round tank, data showed that dead fish values in Nile tilapia stocking density of $100 \mathrm{fish} / \mathrm{m}^{3}$ were 0,0 and $4 \mathrm{fish} / \mathrm{m}^{3}$ under aeration regimes $\mathrm{A} 1, \mathrm{~A} 2$, and $\mathrm{A} 3$, respectively. While dead fish values at stocking density of $150 \mathrm{fish} / \mathrm{m}^{3}$ were 0,2 and $6 \mathrm{fish} / \mathrm{m}^{3}$. Also, the dead fish values at stocking density of 200 fish $/ \mathrm{m}^{3}$ were 3,6 and $10 \mathrm{fish} / \mathrm{m}^{3}$ under the same previous conditions. Considering the square tank, data showed that dead fish values in Nile tilapia stocking density of $100 \mathrm{fish} / \mathrm{m}^{3}$ were 0,6 , and $8 \mathrm{fish} / \mathrm{m}^{3}$ under aeration regimes $\mathrm{A} 1, \mathrm{~A} 2$, and $\mathrm{A} 3$, respectively. While dead fish values at stocking density of $150 \mathrm{fish} / \mathrm{m}^{3}$ were 6,7 and 11 $\mathrm{fish} / \mathrm{m}^{3}$. Also the dead fish values at stocking density of $200 \mathrm{fish} / \mathrm{m}^{3}$ were 9,10 and $14 \mathrm{fish} / \mathrm{m}^{3}$ under the same previous conditions.
The dead fish of Nile tilapia increased with increasing stocking density. The highest values of dead fish were achieved under high density (200 fish $/ \mathrm{m}^{3}$ ) compared to those reared under densities of 100 and $150 \mathrm{fish} / \mathrm{m}^{3}$ at the whole of the experimental period. This could be attributed to that at high stocking densities, the ammonia concentration increased and at the same time dissolved oxygen decreased resulting in an increase of dead fish.

The results showed that the lowest dead fish was $0 \mathrm{fish} / \mathrm{m}^{3}$ which achieved under aeration regime A1 (aeration by air compressor with inter-holes distance of $150 \mathrm{~mm}$ ) with the use of either round or square tanks and density of 100 fish $/ \mathrm{m}^{3}$. 
Effect of Aeration Regime on Body Weight Gain of Tilapia for Round and Square Tanks under Different Stocking Densities

Fig. 10 shows the relationship between aeration regime and body weight gain for both round and square tank using different stocking densities.

Concerning the round tank, data showed that body weight gain values in Nile tilapia stocking density of $100 \mathrm{fish} / \mathrm{m}^{3}$ were 78.8, 77.2 and 74.1 g/fish under aeration regimes A1, A2, and A3, respectively. While body weight gain values at stocking density of $150 \mathrm{fish} / \mathrm{m}^{3}$ were $75.5,73.6$ and $71.1 \mathrm{~g} /$ fish. Also the body weight gain values at stocking density of $200 \mathrm{fish} / \mathrm{m}^{3}$ were 68.7, 66.7 and $64.1 \mathrm{~g} /$ fish under the same previous conditions. Considering the square tank, data showed that body weight gain values in Nile tilapia stocking density of $100 \mathrm{fish} / \mathrm{m}^{3}$ were $77.8,75.8$ and $73.8 \mathrm{~g}$ /fish under aeration regimes A1, A2, and A3, respectively. While body weight gain values at stocking density of $150 \mathrm{fish} / \mathrm{m}^{3}$ were 74.6, 72.2 and $70.4 \mathrm{~g} /$ fish. Also, the body weight gain values at stocking density of $200 \mathrm{fish} / \mathrm{m}^{3}$ were $66.4,65.3$ and 63.4 $\mathrm{g}$ /fish under the same previous conditions.

The body weight gain of Nile tilapia fish decreased with increasing stocking density. The highest body weight gain values were achieved under stocking density of $100 \mathrm{fish} / \mathrm{m}^{3}$ compared to those reared under densities of 150 , and 200 fish $/ \mathrm{m}^{3}$ at the whole of the experimental period. That findings are in agreement with Ridha (2006) who found that high conversion ratio of Nile tilapia was observed at high stocking densities, resulting in decrease in body weight gain.

The results showed that the highest body weight gain (78.8 g/fish) was achieved under fish density of $100 \mathrm{fish} / \mathrm{m}^{3}$ and the better aeration regime was A1 (aeration by air compressor with interholes distance of $150 \mathrm{~mm}$ ) with using the round tank to increas the body weight gain of fish.

\section{Effect of Aeration Regime on Specific Growth Rate of Tilapia for Round and Square Tanks under Different Stocking Densities}

Fig. 11 shows the relationship between aeration regime and specific growth rate under different stocking densities for both round and square tanks.

Concerning the round tank, data showed that specific growth rate values in Nile tilapia stocking density of $100 \mathrm{fish} / \mathrm{m}^{3}$ were 72,70 and $66.7 \%$ under aeration regimes $\mathrm{A} 1, \mathrm{~A} 2$, and $\mathrm{A} 3$, respectively. While specific growth rate values at stocking density of $150 \mathrm{fish} / \mathrm{m}^{3}$ were 68,66 and $61.7 \%$. In addition, the specific growth rate values at stocking density of $200 \mathrm{fish} / \mathrm{m}^{3}$ were 61,59 and $56 \%$ under the same previous conditions. Concerning the square tank, data showed that specific growth rate values in Nile tilapia stocking density of $100 \mathrm{fish} / \mathrm{m}^{3}$ were 70.6, 68.5 and $66 \%$ under aeration regimes $\mathrm{A} 1$, A2, and A3, respectively. While specific growth rate values at stocking density of $150 \mathrm{fish} / \mathrm{m}^{3}$ were $67,64.8$ and $60.8 \%$. Also, the specific growth rate values at stocking density of 200 fish $/ \mathrm{m}^{3}$ were $58.8,57.6$ and $55 \%$ under the same previous conditions. This is in agreement with Azim et al. (2003) and Liti et al. (2005) who found that specific growth rate of tilapia was higher at low fish stocking densities.

The results showed that the specific growth rate decreased with increasing fish densities, and the highest specific growth rate was $72 \%$ under aeration regime A1 (aeration by air compressor with inter-holes distance of $150 \mathrm{~mm}$ ) with using round tank.

Effect of Aeration Regime on Relative Growth Rate of Tilapia for Round and Square Tanks under Different Stocking Densities

Fig.12 shows the relationship between aeration regime and relative growth rate under different stocking densities for both round and square tanks.

Concerning the round tank, data showed that relative growth rate values at Nile tilapia stocking density of $100 \mathrm{fish} / \mathrm{m}^{3}$ were 688,672 , and $641 \%$ under aeration regimes A1, A2 and $\mathrm{A} 3$, respectively. While relative growth rate values at stocking density of $150 \mathrm{fish} / \mathrm{m}^{3}$ were 655,636 , and $592 \%$. Also the relative growth rate values at stocking density of $200 \mathrm{fish} / \mathrm{m}^{3}$ were 587, 567 and $531 \%$ under the same previous conditions. Concerning the square tank, data showed that relative growth rate values at 

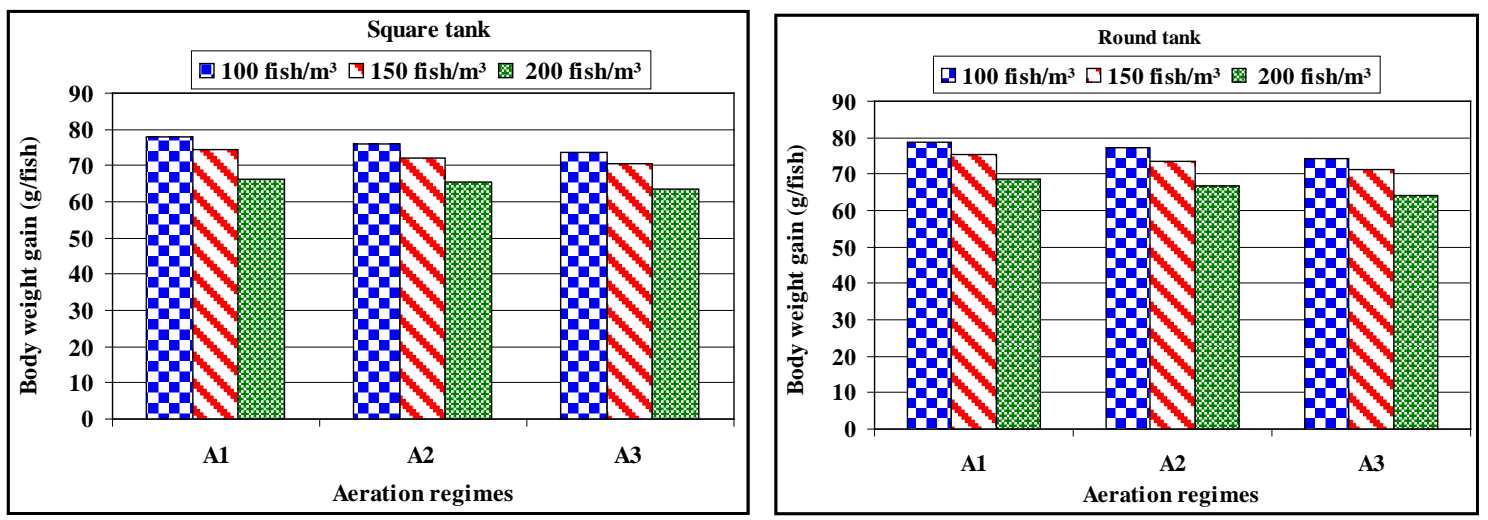

Fig. 10. Effect of aeration regime on body weight gain of tilapia in round and square tanks under different stocking densities
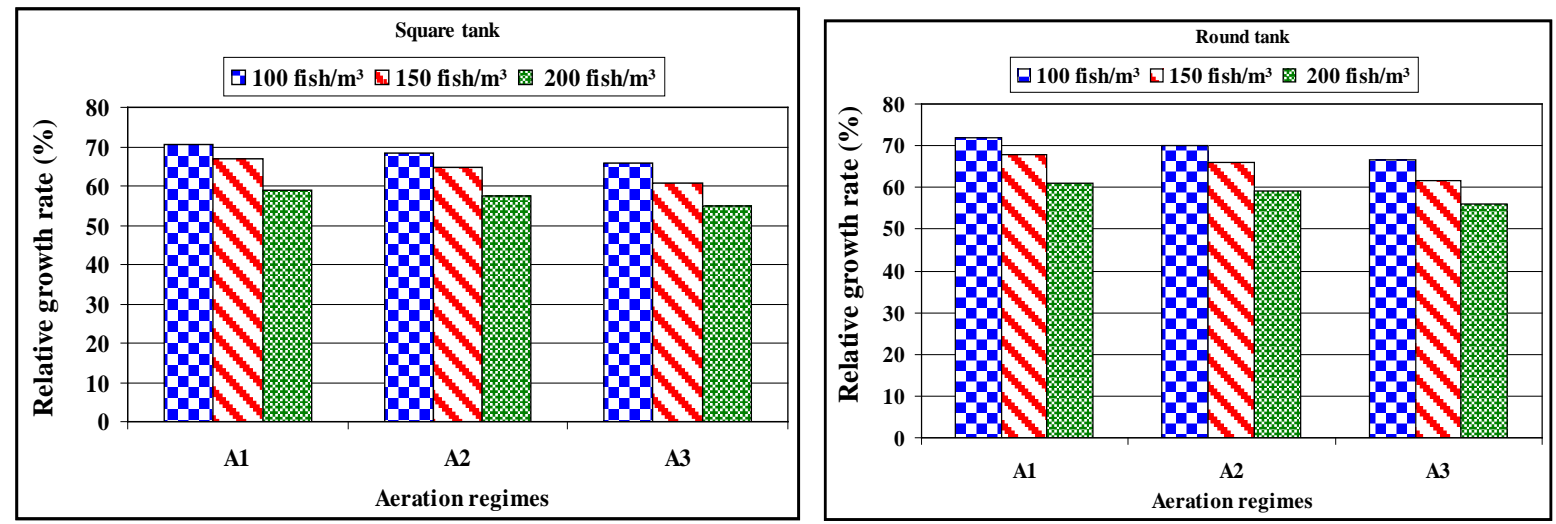

Fig. 11. Effect of aeration regimes on specific growth rate of Nile tilapia in round and square tanks under different stocking densities
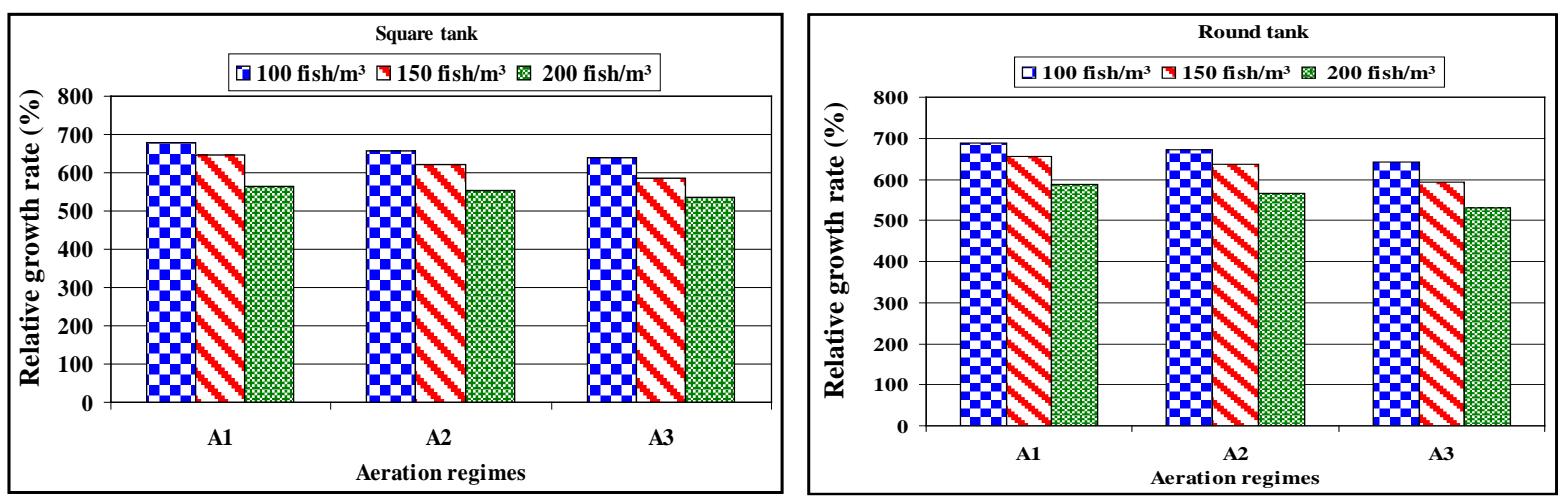

Fig. 12. Effect of aeration regimes on relative growth rate of Nile tilapia in round and square tanks under different stocking densities 
Nile tilapia stocking density of $100 \mathrm{fish} / \mathrm{m}^{3}$ were 678, 658 and 638\% under aeration regimes A1, A2 and A3, respectively. While relative growth rate values at stocking density of $150 \mathrm{fish} / \mathrm{m}^{3}$ were 646, 622 and 584\%. In addition, the relative growth rate values at stocking density of $200 \mathrm{fish} / \mathrm{m}^{3}$ were 564,553 , and $534 \%$ under the same previous conditions.

The results showed that the relative growth rate decreased with increasing fish densities, and the highest relative growth rate (688\%) was obtained under aeration regime A1 (aeration by air compressor with inter-holes distance of 150 $\mathrm{mm}$ ) with using round tank.

\section{Effect of Aeration Regime on Required Power (kW)}

Fig. 13 shows the relationship between the aeration regime and required power $(\mathrm{kW})$, results showed that required power values were
0.900, 0.741 and $0.556 \mathrm{~kW}$ under aeration regimes A1, A2, and A3, respectively. The required power increased with increasing the total air flow rate of pumped air.

The results showed that the highest required power of $0.900 \mathrm{~kW}$ was achieved under Aeration by air compressor with inter-holes distance of $150 \mathrm{~mm}$ (A1) corresponding to air flow rate of $0.018 \mathrm{~m}^{3} / \mathrm{sec}$, due to the highest pumped airflow rate.

\section{Conclusion}

The experimental results revealed that biomass $\left(13.53 \mathrm{~kg} / \mathrm{m}^{3}\right)$ was maximum while dead fish $\left(3 \mathrm{fish} / \mathrm{m}^{3}\right)$ was optimum under the following conditions:

- Use of the round fish tank

- Use of air compressor with inter-holes distance of $150 \mathrm{~mm}$ as an aeration regime

- Adjust stocking density at $200 \mathrm{fish} / \mathrm{m}^{3}$

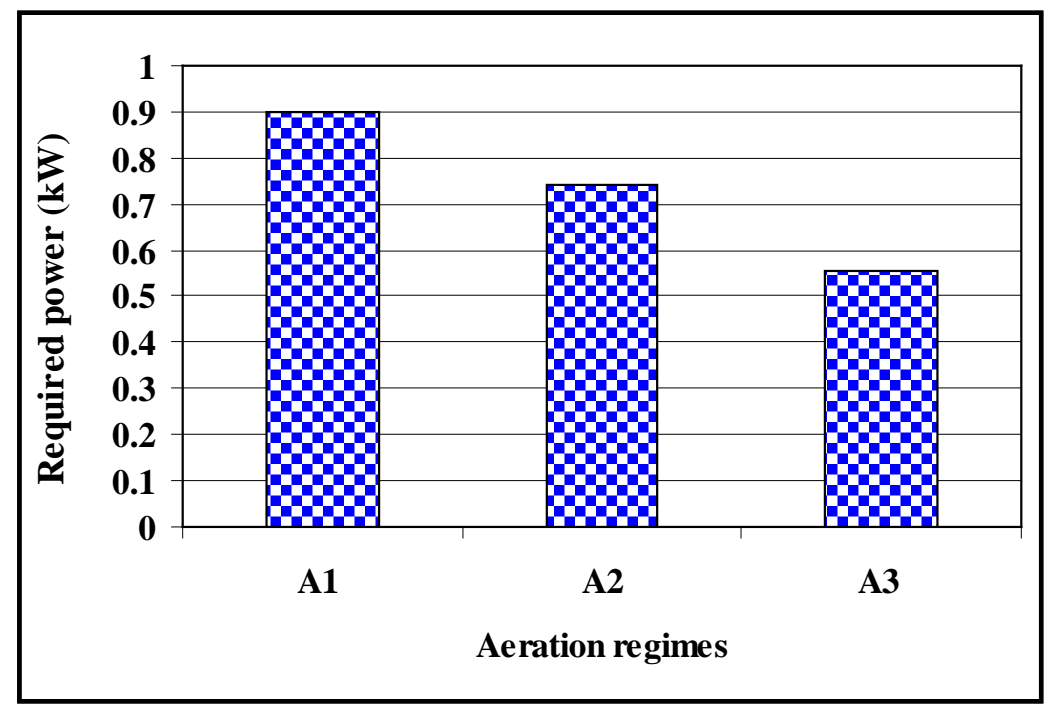

Fig. 13. Effect of aeration regime on required power 


\section{REFERENCES}

Abdelhamid, A.M. (2003). Scientific Fundamentals for Fish Production and Management. $2^{\text {nd }}$. Ed., Deposit No. 15733, Mansoura Univ., Press.

Aksungur, N., M. Aksungur, B. Akbulut and I. Kutlu (2007). Effects of stocking density on growth performance, survival and food conversion ratio of turbot (Psetta maxima) in the Net Cages on the Southeastern Coast of the Black Sea. Turkish J. Fisheries and Aquatic Sci., 7: 147-152.

APHA (1990). American Public Health Association, American Water Works Association and Water Pollution Control Federation. Standard Methods for the Examination of Water and Waste Water, $17^{\text {th }}$ Ed. Am. Public Health Assoc., Washington D C.

Ayyat, M.S., H.I. EI-Marakby and S.M. Sharaf (2011). Effect of dietary protein level, stocking density, and dietary pantothenic acid supplementation rate on performance and blood components of nile tilapia Oreochromis niloticus. J. Appl. Aquac., 23 (2): 122 - 135.

Azim, M.E., M.C.J. Verdegem, M. Singh, A.A. Dam and M.C.M. Beveridge (2003). The effects of periphyton substrate and fish stocking density on water quality, phytoplankton, periphyton and fish growth. Aquac. Res., 34:685-695.

Boyd, C.E. (1998). Pond water aeration systems aquacultural engineering, Elsevier Sci., England, 18 : 9-40.

Central Agency for Public Mobilization and Statistics (2011).

Cruz, E.M. and R.C. Delacruz (1991). Production of common carp Cyprinus capio with supplemental feeding in rice field in North Sumatra, Indonesia. Asian Fish. Sci., 4:3139.

EI-Sayed, A.F.M. (2002). Effects of stocking density and feeding levels on growth and feed efficiency of Nile tilapia (Oreochromis niloticus L.) fry. Aquac. Res., 33 (8): 621626.
EI-Sayed, A.F.M., A. EI-Ghobashy and M.M. AI-Amoudi (1996). Effects of pond depth and water temperature on the growth, mortality and body composition of Nile tilapia, Oreochromis niloticus (L.). Aquac. Res., 27: 681- 687.

FAO (2012). Fisheries and Aquaculture Department has published the Global Aquaculture Production Statistics for the year 2011.

Ibrahim, M.K.E. (1982). Wet milling of wheat grain, M. Sc. Thesis Fac. Agric. Mansoura Univ.

Laird, L. and T. Needham (1988). Salmon and Trout Farming. Harwood, New York.

Li, Y.Q., H.Y. Zhang, J. Li, Q.Y. Wang and Z.D. Li (2008). Utilization of liquid oxygen in intensive shrimp aquaculture. Fisheries Sci. Dalian., 27 (8): 401-403.

Liti, D., B. Fulanda, J. Munguti, M. Straif, H. Waidbacher and G. Winkler (2005). Effect of open - pond density and caged biomass of Nile Tilapia (Oreochromis niloticus, L.) on growth, feed utilization, economic returns and water quality in fertilized ponds. Aquac. Res., 36: 1535 - 1543.

Lopa G. and G.N. Tiwari (2008). Computer modeling of dissolved oxygen performance in greenhouse fishpond: an experimental validation. Int. J. Agric. Res., 3 (2) : 83-97.

Ridha, M.T. (2006). Comparative study of growth performance of three strains of Nile tilapia, Oreochromis niloticus, L. at two stocking densities. Aquac. Res., 37(2): 172-179.

Teichert, C.D. and B.W. Green (1993). Tilapia yield improvement through maintenance of minimal oxygen.

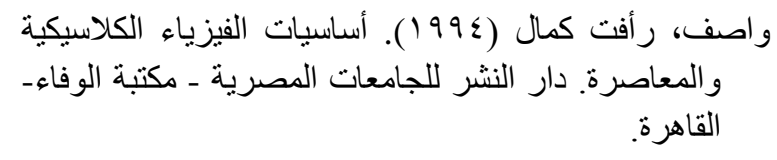




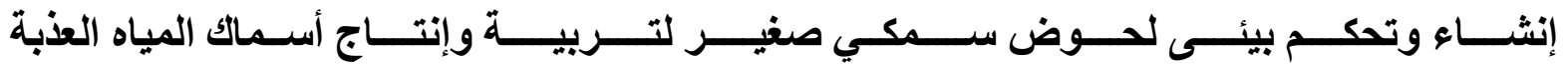

صفاء السيد غريب محمد' ـ محمد محمد مراد حسن' ـ هند أحمد مجدى المغاوري ' ـ عبد الرحمن إبراهيم عبدالرحمن'

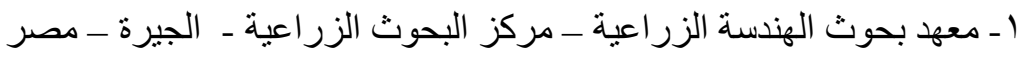

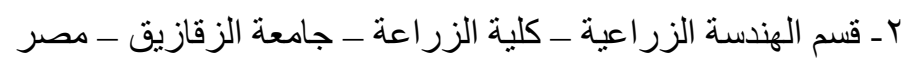

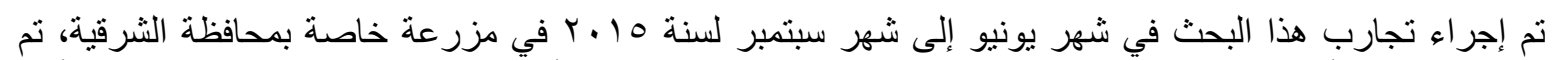

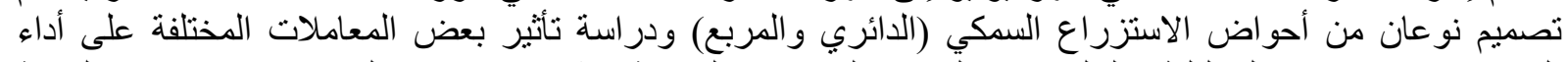

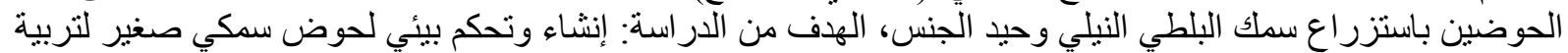

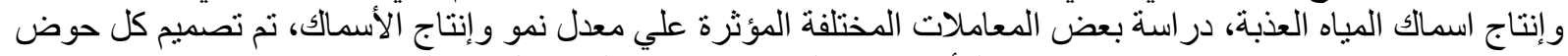

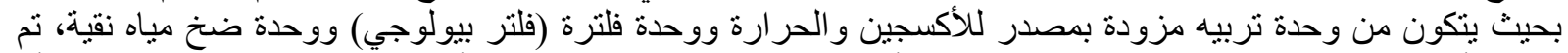

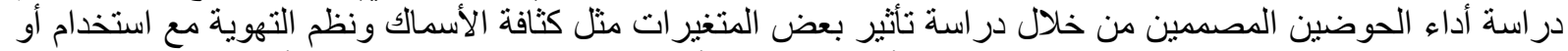

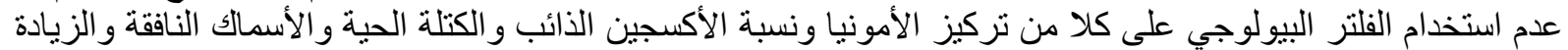

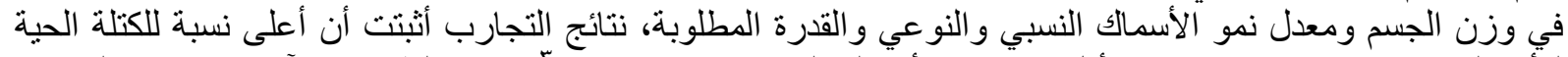

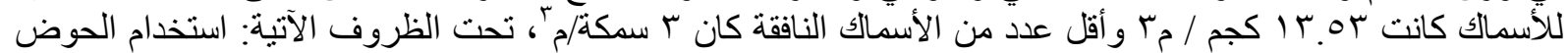

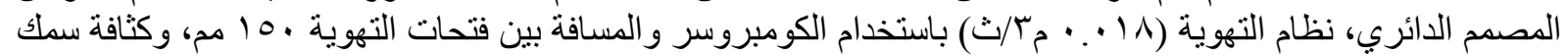

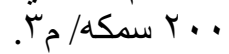

